ORIGINAL ARTICLE

\title{
Dr Bruno Sachs addresses an audience of first year medical students: an extract from the writing of Martin Winckler, French doctor and writer
}

\author{
D Jeffries, M Winckler
}

J Med Ethics; Medical Humanities 2006;32:1-3. doi: 10.1136/jmh.2005.000227

One of the authors of this paper (DJ) has been impressed by the work of the second author (MW) for some time. On reading one of his works, Les Trois Médecins, DJ was so struck by a particular passage that he attempted a translation. He received not only permission from Winckler to seek publication but also help with the translation. Along with that translation, which forms the body of this article, the passage has been set in context by $\mathrm{MW}$, who also provides some explanation of it. It is DJ's hope that the article will prove stimulating in its own right, and also lead some readers at least to seek out more of Winckler's work.

See end of article for authors' affiliations

Correspondence to D Jeffries, Top Flat, Rocky Hill, St Mary's, Isles of Scilly TR21 ONE, UK. dieffries@onetel.com

Accepted for publication 10 January 2006 first came across the work of Martin Winckler about six years ago, and was intrigued enough by a book review to get hold of a copy of Winckler's novel, La Maladie de Sachs. The novel proved to be an unexpected bestseller, was chosen by readers for the Prix du Livre Inter, has sold 600000 copies in France alone, was made into an acclaimed film, and has been translated into several languages, including English. The English translation, The Case of Dr Sachs, was published in 2000. The novel is recommended reading in many European medical schools and in the American medical community, yet, it has not had the success that it richly deserves in the UK. This is something of a puzzle, as the portrait that it paints of a compassionate, complex, and committed rural general practitioner is one that we can easily recognise and sympathise with, and one that owes an explicit debt to the ideals of the Balint school so beloved of educators in general practice in the UK.

Winckler has also published detective fiction, commentaries on television series and American comic books that occupy a prominent place in his personal cultural interests, and collections of essays on medical and medicopolitical topics. He has also broadcast regularly on French radio. He continues to work in family planning and has written the first French textbook on the subject, which is accessible to patients and doctors alike. Most recently, he has returned to his alter ego, Dr Bruno Sachs, to recount his days as a medical student, under the title Les Trois Médecins. The allusion to Alexandre Dumas's great historical adventure, The Three Musketeers is deliberate, and Winckler shamelessly borrows characters from
The Three Musketeers and follows its plot precisely, transposing them to a 1970s French medical school. Readers do not need to be familiar with Dumas's novel to appreciate Winckler's, although I imagine that it may add to the entertainment value and excuse some of its more melodramatic moments.

On reading Les Trois Médecins, I was so struck by one passage that I attempted a translation, which I sent to Martin Winckler for his interest, and to see whether he would give me permission to seek its publication. To my delight he was enthusiastic, and helped me with some of the more colloquial phrases. The result is a loose translation that attempts to remain faithful to the spirit of the original, but uses idiomatic English when it seems more natural. Martin has kindly added some explanation of the passage and set it in context. We hope that it will prove stimulating in its own right, and lead some readers at least to seek out more of Winckler's work.

\section{EXPLANATORY COMMENTS (MW)}

This chapter can be found at the end of Les Trois Médecins. Bruno Sachs, a seasoned general practitioner who has become a writer, has been invited by three old friends-now all occupied in medical training in their alma mater-to give a lecture to first year medical students. The topic: "Becoming a doctor". While Bruno is on his way to the auditorium, his friends meet up and recall the story of how they were trained as care givers. Their recollections-a retelling of Alexandre Dumas's The Three Musketeers-form the bulk of the book. In this chapter, when Bruno appears, he finds himself facing several hundred students and, as past and present, ideals and reality, clash in his mind, he wonders what he is going to say. What follows is a mixture of both his hesitating thoughts and the words he will finally utter.

\section{THE TRANSLATION}

There are six hundred, eight hundred, a thousand of them: it's incredible for me to be speaking to all these young people, who are like we were thirty years ago. I look at them, and I ask myself how I am going to begin. As they are making such a noise, as they perhaps don't want to hear me pontificate, I tell myself I'm like them: lectures bore me. How am I going to make them understand that I'm not here to teach them life but perhaps simply to tell them about mine. And then it comes back to me-I raise my arm, I point toward a boy way up over there, I crease up 
with laughter, the lecture theatre murmurs. They must be thinking: He's crazy, this guy, seeing me laughing like this all on my own, this is a medical lecture theatre here, who is this clown?

"You know why I'm laughing?"

I raise my arm, I point.

"Because twenty five years ago, I was sitting right there. And on the other side, down there (I point to a place further away), there was a girl-I Got You, Babe-who I was dying to sit next to...only there were thirty guys in my way!"

It's their turn to laugh; they understand me: I may be crazy, but it's a change from the usual starched profs who come and speak here. I haven't prepared anything; I've been ready for so long. I haven't come to give them a lecture; I've come to tell them what I haven't been able to say till now. I don't know quite what's coming; I only know what I would like to tell them. There's so much and I can't say it all. What do my friends expect?

That in two hours I can tell them everything they're going to spend ten years learning? I can't do it: I'm not even sure that I can tell them the bare essence, given that I hardly know it, given that I'm only just beginning to see it, now that the words are no longer stuck in my throat, now that I've started to write again. I can try to tell them: I know what they keep telling you: "You won't all be doctors".

But I don't give a damn about that, it hardly matters that some of you will be admitted to medical school and others won't. If you want to care, you will care, as doctor, nurse, physio or whatever. Today, if you're sitting here it's because you're all potential care givers, and that's why I'm speaking to you, laying out the simple things, the ideas, ultimately, that I've embraced since adolescence, the pent up anger that's begging to be released, all that I've suffered, all that they are going to make you suffer: the feudalism of medical education, the archaicism of the teaching methods ${ }^{\mathrm{ii}}$ the criminal hierarchy of the hospital, the inept competition that's built up between students and continues between care givers, the bloody struggle for power, the mutual mistrust, the arrogance, the vanity of which your elders are evidence, of which you yourselves will perhaps be evidence, all that they're not going to be told in their studies: the confused reasons for becoming a doctor, the obligatory motives: I want to look after people, the innocent desires that know nothing of life, the fears exactly the same, no more, no less, as those of the people you're going to be looking after, without ever forgetting what the powers that be would like to make them forget-their deepest feelings, their hidden pains, their unconscious need to care for themselves and to heal unwittingly their own sufferings-archaic, familial, unknown-hidden in their own depths; the appetite for revenge, the everyday sadism, the taste for dominance that so many doctors don't know that they carry in themselves, or pretend not to know. Diseases are abstract concepts that have nothing to do with the individual person; nobody is reducible to a diagnostic grill, however sophisticated it might be; and what counts in life, is not so much health as meaning, and that's something a lot of doctors completely fail to understand. You will always be caught between the corrupt ideology, our own, that our "masters" have inculcated in us, and the insistent, irreducible personality, the authentic selfhood of the people who confide in us. Because, to care for people, you have to know the world we live in: the real world, abject, unfeeling and brutal; the alienating job, the all consuming family; social injustice, misery, war .... There are two things above all that they won't talk to you about here, at least not in asking what they mean for you, and

inly a small percentage of students admitted for the first year of studies will be selected for the full course in medicine.

ii "Enseignement magistral": literally, the teaching in an auditorium by a teacher who will not accept any interaction from his students, still common practice in French medical schools. these are sex and death-you who are listening to me, there are eight hundred, a thousand of you; do you really believe that not one of you will be dead by the end of the year? I hear them murmuring: "I can't believe it! What's he up to, does he want to bring us bad luck?" It's not a threat nor a prediction, not a curse nor a probability: it's a reality, because within the last fortnight two of your comrades have killed themselves....Yes indeed, most of you don't know about it, but if you don't know, how can you help their friends, those who do know and are torn apart and are weeping and are petrified by seeing someone disappear who was alive a few weeks ago? And even if you couldn't care less because you didn't know them, I would be surprised if no one close to you, maybe in your own family, had died. When you become a doctor you think you can care for those you love-parents, friends, lovers, children-that you can spare them from death; but for certain everyone sees those close to them suffer and die, sometimes without being able to do anything, you just like all the rest. And if you don't think about death, about your own death, in six months, in twenty years, in bed or in a car, with a drip in your arm or under a train, too young or too old, all alone or loved and supported, how do you expect to understand what people will tell you when they come to talk about their death or the death of their loved ones? As for sex ...-I can see their ears prick up and that's not all-that's how human life is made. It's a cocktail of desires, frustrations, attractions, reasons, expectations, meetings, departures, joy, sadness, happiness and, with luck, pleasure. There are eight hundred or a thousand of you here, don't tell me you're all virgins, of course they'll start shouting and the song will ring out "Let's all cheer/Doctor Sachs's a dandy/Still feeling randy/Still feeling randy ..., ${ }^{\text {iii }}$

..But what are you thinking, do you believe I've forgotten that when I was your age, it was enough for me to come across a low neckline to feel randy-it still happens! And if some of you have been having sex for a long time others may do it for the first time tonight or this afternoon in the empty flat when the parents are away, I want you so much, I'm frightened but I want to, let's make love, let's make love? It'll be good for us or in a year and some are content and some are forced into it and if you don't think about what it means, about the place that sex occupies in your life, how do you expect to understand what it is that people come to tell you. How can I tell them clearly that to care is not, it is not in any way to wear a white coat and a stethoscope, to imbibe books and recipes and lessons in ethics and conduct. To care does not have anything to do with competence or ethics or titles, nor is it gaining knowledge to win power: power is deadly while to care is the same as to love to educate to share to bring up to accompany to carry to guide, it's living it's vibrant it's good it's warm it's tender like the mouth of the lover who murmurs and who breathes warmth and cold on our embracing bodies to care is to move towards the other, because it's the other who teaches us, it's the other who tells us where the pain lies, where the relief is to be found, and if I've learnt to care, however little it may be, to build a few derisory but worthwhile defences against suffering it's thanks to others who have shown me, to care is to respect, the doctor who treats other care givers as underlings is a bastard, the doctor who guards knowledge without sharing it with those who need it is a crook, the doctor who uses his white coat his title his stethoscope to exercise power is a criminal, the doctor who reserves his loyalty for his colleagues is a felon. To care is to take action and support the cause of those who suffer, it is to be, first and foremost, loyal to oneself, toward one's ideals, toward those for whom one cares, be it even against one's colleagues. The doctor who respects himself and respects others isn't content to carry out what he's been taught in a servile way but asks himself every

iii The song is one that students usually sing when a teacher makes an innuendo (voluntary or not) in one of his classes. 
day if he couldn't do better-without pretending he's God Almighty.

Because there's no such thing.

Because there's only us in this immense universe, the universe of suffering ....

How can I tell them all that without getting lost?

How can I tell them that to care, one can't learn it with a pen on a page, but with eyes on the lips and fingers on the skin and one's mouth by the ear and my body on your body ...?

How can I tell them that caring is like living, you don't wait until you've learned, you do it right away!

How can I tell them that caring is something you learn from others-all the others: those whom one admires, those whom one detests, those who make us sick and those who attract us, those who frighten us and mistreat us, those who support us and those who are hostile, our friends and our enemies, our brothers and our sisters, those who are sitting here around us and that we don't know, and who all have something to tell us if only we were willing to lend them an ear, if only we were willing to lend them a hand.

How can I tell them that one learns to care by being oneself because everything is here, in my body made to enjoy and made to suffer, identical to the other's body, and it's there alone that we can draw from to understand what the fuck we're doing here. Because your body, my other half, is always foreign to me even if I lose myself in it, and it's in my own body-and only in my own-that I feel, that I know if you suffer, if you enjoy, if I care for you or if I torment you!

How can I tell them that caring is like writing: it's something one does all the time, just by being aware of those around us, thinking every second about the other person and what makes them suffer and what might perhaps make them feel better.

How can I tell them that one cares as one writes: with one's desire, with one's anger!

I don't know how I'm going to tell them all that. I don't know if what I have to say will mean anything to them. I don't know if set against the lectures of all the mandarins, of all the teachers who've taken this lectern, my ramblings will carry any weight. I know that they'll be told: Once a doctor, always a doctor, and I'll tell them: it's false. Don't forget: you haven't always been a doctor! I know that they'll be told: In every doctor there's a scientist, a care giver, a teacher, and I'll tell them: perhaps, but never let knowledge muzzle your feelings, don't quibble at the expense of those who are in pain, and never ever forget that inside each care giver there are three persons: the one who feels, the one who doubts, the one who shares. Don't forget, in the end: there are not doctors on the one hand and everyone else on the other, there are only lives and the words of human beings, those who speak them, those who read them and speak them in their turn ....

... I don't know how I'll tell them all that, nor even if I'll manage to say the half of it, but as I've got to begin somewhere, I'll begin by telling them:

Good morning. My name's Bruno Sachs and, like all of you here-but for me it's been for thirty years-I am learning to become someone who cares ...."

\section{SELECTED BIBLIOGRAPHY OF MARTIN WINCKLER}

La Maladie de Sachs. POL éditeur, 1998.

The Case of Dr Sachs. Seven Stories Press, 2000.

En Soignant, en Écrivant. Indigènes éditions, 2000.

C'est Grave, Docteur? La Martinière, 2002.

Contraceptions Mode d'Emploi [2nd ed]. Le Diable Vauvert, 2003.

Les Trois Médecins. POL éditeur, 2004

\section{Authors' affiliations}

D Jeffries, General Practitioner, St Mary's, Isles of Scilly TR21 ONE, UK M Winckler, 27 Rue de la Boussinière, F 72000 Le Mans, France

Colloquium: Circles Within Circles: qualitative methodology and the arts: the researcher as artist

The starting point for this exciting two-day event is the idea that there is an emerging 'edgelands' in qualitative enquiry (Rapport et al 2004; 2005) - a space between established and new methods where new approaches are being developed, new theories examined and new ways of asking and answering questions formed that do not conform to neatly regulated patterns of events or outcomes. The Colloquium builds on this idea by focusing on links between New Qualitative Methodologies and the Arts to explore what happens when researchers and artists, talk to one another. There will be presentations from qualitative methodologists within the strands: narrative based, arts-based and re-defined methodology, whilst artists will be encouraged to discuss their work whilst they create or perform, in terms of the productive process and expressive representation. Working side by side will encourage a cross-fertilisation of applications and ideas.

The colloquium will take place at the The School of Medicine, Swansea University on 19 and 20 September. For further details please contact v.i.davies@swan.ac.uk, or via www.swan.medicine.ac.uk/events 